\title{
Some ecological aspects of free-living Haemaphysalis juxtakochi Cooley, 1946 (Acari: Ixodidae) in Panama
}

\author{
Algunos aspectos ecológicos de fases de vida libre de \\ Haemaphysalis juxtakochi Cooley, 1946 (Acari: Ixodidae) \\ en Panamá
}

\author{
Gleydis García G, ${ }^{1}$ Lic, Angélica Castro DF, ${ }^{1}$ Lic, Sergio Bermúdez C, ${ }^{1 *}$ M.Sc, \\ Santiago Nava, ${ }^{2}$ Ph.D.
}

\begin{abstract}
${ }^{1}$ Instituto Conmemorativo Gorgas de Estudios de la Salud, Ciudad de Panamá, Panamá 081602593. ${ }^{2}$ Instituto Nacional de Tecnología Agropecuaria, Estación Experimental Agropecuaria Rafaela y Consejo Nacional de Investigaciones Científicas y Técnicas, CC 22, CP 2300 Rafaela, Santa Fe, Argentina.*Correspondencia: bermudezsec@gmail.com
\end{abstract}

Received: February 2013; Accepted: November 2013.

\begin{abstract}
Objective. To describe the seasonal variation and perform a comparative analysis on habitat preference of Haemaphysalis juxtakochi in Panama. Materials and methods. Ticks were collected from the vegetation, using a white cloth, between January 2009 and March 2010, in four site located in Summit Municipal Park (SMP), two in wooded area (WA) and two in grasslands (GR).The ticks were determined as larvae, nymphs and adults of $H$. juxtakochi. The number of ticks collected in each area was employed to describe the seasonal distribution of both immature and adult stages, and the non-parametric Mann-Whitney $U$ test. Results. A total of 2.338 ticks in WA and 560 ticks in GR were collected. The major peak of adults from May to July, nymphs peaked from January to April and the peak of larvae abundance from December and January. There was a significant difference in the number of ticks collected in the two areas for each tick stage (larvae, mean number (MN) in WA 120.14, MN in GR 57.07, P: 0.02; nymphs, MN in WA 46.42, MN in GR 16.38, P: 0.018; adults, MN in WA 6.64, MN in GR 1.78, P: 0.02). Conclusions. The results suggest that $H$. juxtakochi maintains a one-year cycle in the study areas. This cycle would be characterized by the immature population peaks in the dry season; while adults are distributed throughout year, with a peak in the transition from the rainy and dry. Moreover, $H$. juxtakochi was more abundant in forests than in grasslands, which could lead to a better adaptation to forested conditions.
\end{abstract}

Key works: Abundance, distribution, environment, host, stages, ticks (Source: DeCYT).

\section{RESUMEN}

Objetivo. Describir la variación estacional y realizar un análisis comparativo de la preferencia de hábitat de $H$. juxtakochi en Panamá. Materiales y métodos. Se recolectaron mensualmente garrapatas de la vegetación utilizando una tela blanca, entre enero de 2009 y marzo de 2010 en cuatro sitios establecidos en el Parque Municipal Summit (PMS), dos en área de pastizales (AP) y dos en área boscosa $(A B)$. Las garrapatas fueron identificadas como larva, ninfa y adulto de $H$. juxtakochi. El 
número de garrapatas recolectadas en cada área fue empleado para describir la distribución estacional de ambos estadios inmaduros y adultos, y se compararon con la prueba no paramétrica Mann-Whitney U. Resultados. Se recolectó un total de 2.338 garrapatas en AP y 560 garrapatas en AB. El mayor pico de garrapatas adultas fue de mayo hasta julio, los picos de ninfas fueron de enero hasta abril y los picos de abundancia de larvas desde diciembre hasta enero. Hubo diferencias significativas en el número de garrapatas recolectadas en las dos áreas para cada estadio (número promedio de larvas en $A B$ 120.14, en $A P$ 57.07, P: 0.02; número promedio de ninfas en $A B$ 46.42, en $A P$ 16.38, $P: 0.018$; número promedio de adultos en $A B$ 6.64, en $A P$ 1.78, P: 0.02). Conclusiones. Los resultados sugieren que $H$. juxtakochi mantiene un ciclo de un año en las áreas de estudio. Este ciclo estaría caracterizado por picos poblacionales de ejemplares inmaduros en la época seca; mientras que los adultos se distribuyen a lo largo de todo año, con un pico en la transición entre la época lluviosa y seca. Por otra parte, $H$. juxtakochi fue más abundante en bosques que en pastizales, lo cual podría suponer mejores adaptaciones a condiciones boscosas.

Palabras clave: Abundancia, ambiente, distribución, estadio, garrapatas, huésped (Fuente: DeCS).

\section{INTRODUCCIÓN}

El riesgo espacial y temporal de adquirir una enfermedad transmitida por garrapatas está estrechamente asociado a la distribución, abundancia y la dinámica estacional de los vectores (1). Por lo tanto, el conocimiento de la ecología de las garrapatas es esencial para hacer inferencias epidemiológicas sobre el riesgo de este tipo de enfermedades en una región en particular. La información sobre la ecología de las garrapatas en Panamá es escasa, aun cuando se han realizado estudios sobre su distribución y las relaciones parasíticas con sus hospederos (2-7). De esta manera, no existen caracterizaciones de aspectos ecológicos como la distribución estacional y la preferencia de hábitat de las garrapatas panameñas. Fairchild et al (3) presentan algunas generalizaciones sobre factores ambientales limitantes para la distribución de garrapatas en Panamá, pero sin ningún escrutinio analítico.

Una de las garrapatas con mayor distribución en Panamá es Haemaphysalis juxtakochi (8). Esta especie se ha registrado en varias localidades de Panamá, especialmente en las provincias de Panamá, Colón, Chiriquí, incluso en la isla principal del Parque Nacional Coiba $(4-6,8,9)$. En Panamá los hospederos que se han listado para esta especie incluyen al tapir Tapirus bairdii (macho y hembra), Odocoileus virginianus (macho, hembra, ninfa y larva), Coendou rothschildi (ninfa), Nasua nasua (ninfa) y "pecarí" (ninfa) $(4,9)$. Por otro lado, desde el punto de vista de salud pública, esta especie se ha encontrado parasitando animales domésticos como perros y cabras, además de humanos $(5,6)$.

En Panamá, similar a otros países del Neotropico donde se ha reportado, no se tienen datos sobre la ecología de esta especie (10). Por lo tanto, el objetivo de este estudio fue describir la variación estacional y realizar un análisis comparativo sobre la preferencia de hábitat de $H$. juxtakochi en Panamá.

\section{INTRODUCTION}

The spatial and temporal risk of tickborne disease is closely associated with the distribution, abundance and seasonal dynamics of the vector ticks (1). Therefore, knowledge of ecology of ticks is essential to make epidemiological inferences about the risk of tick-borne diseases in a particular region. Information on ecology of ticks in Panama is scarce. Although studies about host-association and distribution of ticks were carried out in this country (2-7), there are not characterizations of ecological aspects as seasonal distribution and habitat preference of Panamanian ticks. Fairchild et al (3), present some generalizations concerning environmental limiting factors for tick distribution in Panama, but without an analytical scrutiny.

One of the ticks with widely distributed in Panama is Haemaphysalis juxtakochi (8). This species was recorded in several localities from Panama, Colón, Chiriquí Provinces, even in Coiba Island National Park $(4-6,8,9)$. The host recorded for $H$. juxtakochi in Panama were Tapirus bairdii (male and female), Odocoileus virginianus (male, female, nymph and larva), Coendou rothschildi (nymph), Nasua nasua (nymph) and "peccary" (nymph) $(4,9)$. The records with sanitary relevance correspond to domestic mammals as dogs, goats, even humans $(5,6)$.

There is not information about the ecology of $H$. juxtakochi not only in Panama, but neither also in the Neotropics, in spite of its wide distribution in this Biogeographic region (10). Therefore, the aim of this work was to describe the seasonal variation and perform a comparative analysis on habitat preference of H. juxtakochi in Panama. 


\section{MATERIALES Y MÉTODOS}

Área de estudio. El estudio se realizó en el Parque Municipal Summit (PMS), el cual se encuentra localizado en la orilla oriental del Canal de Panamá, a 15 millas de Ciudad de Panamá $\left(9^{\circ} 3^{\prime} 59,9^{\prime \prime} \mathrm{N}\right.$, $79^{\circ} 38^{\prime} 45,98^{\prime \prime}$ ) ). Este parque posee un clima húmedo tropical de acuerdo a la clasificación de Holdridge (11), con una temperatura media de $27^{\circ} \mathrm{C}$; por lo cual la fisonomía que caracteriza el PMS está dada por un bosque húmedo tropical, además de áreas desmontadas que han sido pobladas con la herbácea introducida Saccharum spontaneum, además de otras malezas. Adicionalmente, el PMS está rodeado por el Parque Nacional Soberanía, el cual tiene una superficie aproximada de 1.945 hectáreas de bosque húmedo primario y secundario y posee una alta diversidad, incluyendo 105 especies de mamíferos, 525 de aves, 134 de reptiles $y$ anfibios (4).

Recolección de las garrapatas. Las garrapatas se recolectaron mensualmente de enero 2009 hasta marzo 2010, utilizando una tela blanca $(45 \times 45 \mathrm{~cm})$ que se arrastró sobre la vegetación, además de revisar el envés de hojas. Todas las garrapatas fueron preservadas en etanol al $96 \%$. Se seleccionaron cuatro sitios para la toma de muestras, dos en área boscosa $(A B)$ y dos en área de pastizales $(A P)$, donde se establecieron cuadrículas de $100 \mathrm{~m}^{2}$ para llevar a cabo el muestreo de las garrapatas. En cada sitio se tomaron muestras de 0800-1000 horas. La escogencia de $H$. juxtakochi para este estudio se basó en que la misma es la única especie presente en áreas boscosas de Panamá, cuyos tres estadios pueden ser identificados con certeza. Las garrapatas fueron determinadas de acuerdo a Cooley (8) y Kohls (9).

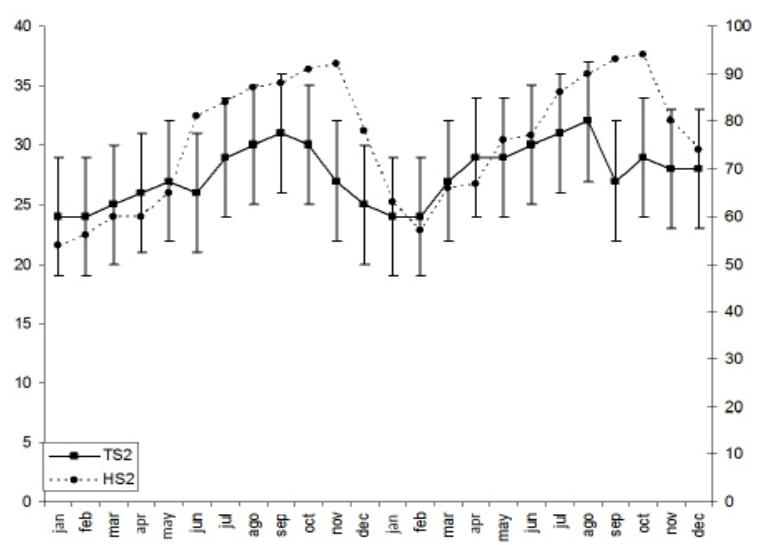

Figure 1. Temperature and humidity Summit Municipal Park, during, 2009-2010.

\section{MATERIALS AND METHODS}

Study area. The study was conducted in Summit Municipal Park (SMP), which is located on the eastern edge of the Panama Canal, 15 miles from Panama

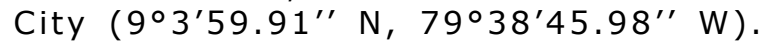
The climate is tropical wet as classified by Holdridge (11), and the average temperature is $27^{\circ} \mathrm{C}$; whereby the physiognomy which characterizes the SMP is given by the tropical rainforest, cleared patches that have been populated with Saccharum spontaneum, and introduced herbaceous and mixed plains. SMP is surrounded by Soberania National Park, which has an approximate area of 1945 hectares of primary and secondary rain forest and has a high diversity, including 105 species of mammals, 525 of birds, 134 of reptiles and amphibians (4).

Ticks collecting. Ticks were monthly collected from vegetation between January 2009 and March 2010, using cloth flags $(45 \times 45 \mathrm{~cm})$ and looking individuals on the undersides of leaves. All ticks were preserved in $96 \%$ ethanol. Four sites were selected for sampling, two in wooded area (WA) and two in grasslands (GR), where grids of $100 \mathrm{~m}^{2}$ were established to carry out the sampling of ticks. Each site was sampled to 0800-1000 hours. Because in Panama only be established with certainty the identification of the three stages of $H$. juxtakochi, the study was emphasized in this species. The ticks were determined following Cooley (8) and Kohls (9).

Statistical analyses. The number of ticks collected in each area was employed to describe the seasonal distribution of both immature and adult stages, and the non-parametric MannWhitney $U$ test with a level of significance of 0.05 was used to compare number of ticks between WA and GR. Temperature and relative humidity were measured monthly in each site (Figure 1).

\section{RESULTS}

Immature and adults of $H$. juxtakochi were collected in both areas, 2338 ticks in WA (1278 larvae, 984 nymphs, 76 adults) and 560 ticks in GR (342 larvae, 195 nymphs, 23 adults). The seasonal variation (expressed as the number of specimens collected in each month, and considering ticks from WA and GR together) in the number of larvae, nymphs and adults of this tick species is presented in figure 2. Although there is a major peak of adults from May to July, they were found during the whole year. Contrarily, larvae and nymphs showed a more 
Análisis estadísticos. El número de garrapatas recolectadas en cada área se empleó para describir la distribución estacional de los estadios inmaduros y adultos y se utilizó la prueba no paramétrica de Mann-Whitney $U$ con un nivel de significancia del 0.05 para comparar el número de garrapatas entre $A B$ y AP. Mensualmente se registró la temperatura y humedad relativa en cada sitio (Figura 1 ).

\section{RESULTADOS}

Se recogieron inmaduros y adultos de $H$. juxtakochi en ambas áreas, 2.338 garrapatas en $A B$ (1.278 larvas, 984 ninfas, 76 adultos) y 560 garrapatas en AP (342 larvas, 195 ninfas, 23 adultos). La variación estacional (expresada como el número de especímenes recolectados en cada mes y teniendo en cuenta las garrapatas de $A B$ y $A P$ en conjunto) en el número de larvas, ninfas y adultos de esta especie de garrapata se presenta en la figura 2 . Aunque se presenta un pico importante adultos desde mayo hasta julio, estos se encontraron durante todo el año. Por el contrario, las larvas y ninfas mostraron un patrón estacional más pronunciado. Las larvas fueron recolectadas desde septiembre hasta marzo, con un pico de abundancia en diciembre y enero, mientras que las ninfas mostraron un pico desde enero a abril.

A pesar todos los estadios de $H$. juxtakochi fueron encontrados en $A B$ y $A P$, hubo una diferencia significativa en el número de garrapatas recolectadas en las dos áreas para cada estadio de las garrapata (número promedio de larvas en $A B$ 120.14, número promedio en $A P$ 57.07, $P$ : 0.02 ; número promedio de ninfas en $A B$ 46.42, número promedio en AP 16.38 , P: 0.018 ; número promedio de adultos en $A B 6.64$, número promedio en AP 1.78, P: 0.02).

\section{DISCUSIÓN}

Nuestros resultados sugieren que $H$. juxtakochi tiene un ciclo de vida anual, al menos en las áreas de estudio. Las larvas que se encontraban activas desde septiembre a marzo debieron haber mudado a ninfas entre enero y abril, y éstas se desarrollaron en garrapatas adultas que alcanzaron un pico de abundancia desde mayo hasta julio.

Dado que es posible encontrar adultos durante todo el año, es probable que las condiciones ambientales en el área de estudio sean adecuadas para una larga supervivencia de estos. Así, el periodo en que los adultos está presentes en el ambiente probablemente esté relacionado con el aumento
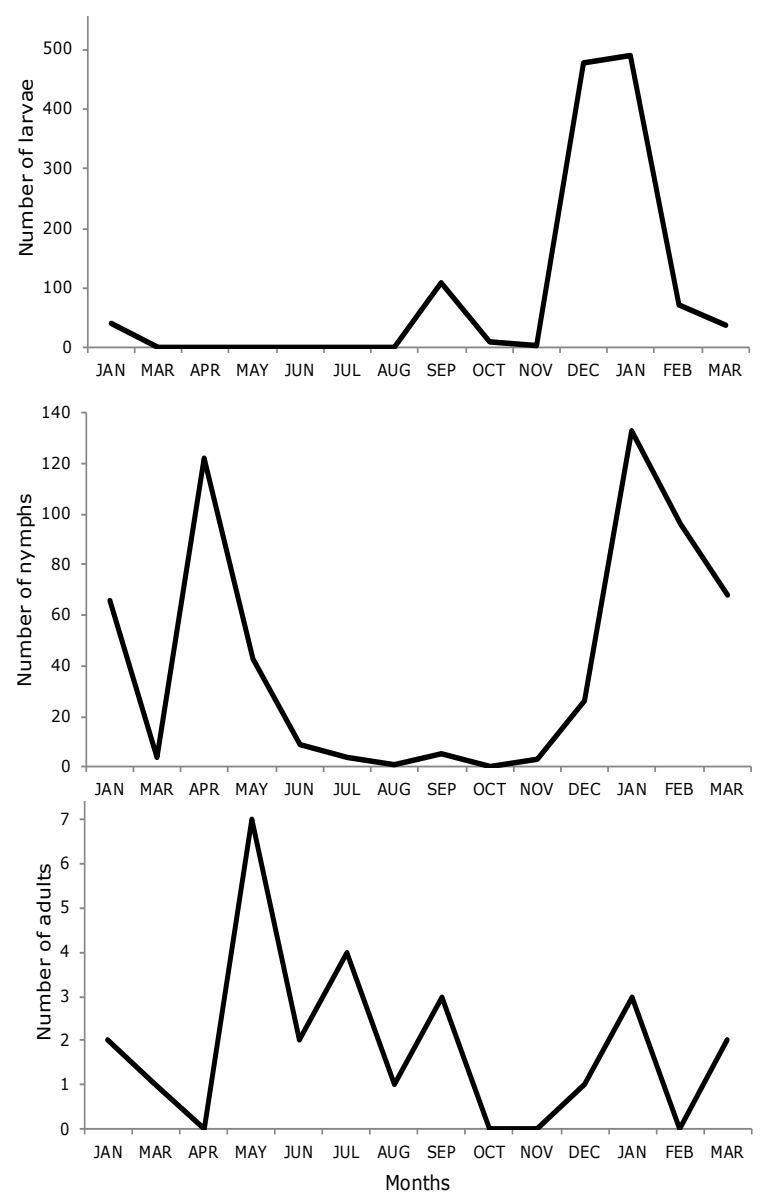

Figure 2. Monthly number of larvae, nymphs, and adults of Haemaphysalis juxtakochi collected on vegetation in Summit Municipal Park, Panama.

pronounced seasonal pattern. Larvae were collected from September to March, with the peak of abundance in December and January, while nymphs peaked from January to April.

Although all stages of $H$. juxtakochi were found in both WA and GR, there was a significant difference in the number of ticks collected in the two areas for each tick stage (larvae, mean number (MN) in WA 120.14, MN in GR 57.07, $P: 0.02$; nymphs, $M N$ in WA $46.42, M N$ in GR 16.38, P: 0.018; adults, MN in WA 6.64, MN in GR 1.78, P: 0.02).

\section{DISCUSSION}

Our results suggest that $H$. juxtakochi has a one-year life cycle, at least in the studies areas. Larvae which were active from September to March emerged into the nymphs present in the environment from January to April, and these nymphs develop into the adult ticks that reach the peak of abundance from May to July. 
en el número de sus hospederos. En el caso de los inmaduros, éstos parasitan principalmete pequeños mamíferos y aves (Bermúdez datos sin publicar). Hasta ahora, en el PMS no se conoce cómo varían las poblaciones de mamíferos o aves a lo largo de las estaciones, conociéndose únicamente el aumento en el número de aves durante la temporada de migración (aprox. noviembre-abril) (12).

Es posible esbozar dos hipótesis para explicar estos resultados. Una de estas está relacionada con el uso de hospederos, ya que la dispersión de las garrapatas depende de la movilidad de los vertebrados. Haemaphysalis juxtakochi es una especie que parasita una amplia gama de hospederos y los adultos se han reportado parasitando mamíferos medianos y grandes pertenecientes a las familias Cervidae, Bovidae, Camelidae, Equidae, Tapiridae, Tayasuidae, además de Canidae, Felidae, Leporidae and Dasypodidae (13). Los estadios inmaduros también parecen ser parásitos oportunistas, ya que se han encontrado asociados a diferentes especies de mamíferos (familia Cervidae, Tayassuidae, Procyonidae, Sciuridae, Leporidae, Dasyproctidae y Erethizontidae) y aves (familias Turdidae, Emberizidae, Corvidae y Falconidae) (13). En Panamá, los principales hospederos de los adultos de $H$. juxtakochi son artiodáctilos, especialmente venado de cola blanca y pecaríes (Bermúdez datos sin publicar), y de éstos, el venado de cola blanca parece ser muy común en la ribera occidental del Canal de Panamá, habitando áreas forestales y pastizales (14).

Así, la capacidad de $H$. juxtakochi de parasitar hospederos con diferentes preferencias ecológicas, permitiría rechazar la hipótesis que el uso del hospedero determina un mayor número de garrapatas en AB. Una segunda hipótesis más plausible se basa en las diferencias en las condiciones microclimáticas en $\mathrm{AB}$ y $\mathrm{AP}$ (12). Es probable que las condiciones microclimáticas en $A B$ sean mejores que en AP para el desarrollo de las fases no parasitarias (muda de larvas y ninfas ingurgitadas, oviposición de hembras ingurgitadas, incubación de huevos, búsqueda de hospederos). Esta hipótesis concuerda con la idea general de que las garrapatas Ixodidae, mantienen un comportamiento más ambiente-específico que hospedero-específico (12); sin embargo, deben diseñarse otros estudios experimentales sobre el estadio no parasitario de $H$. juxtakochi para probar esta segunda hipótesis, además de ser complementada con más datos sobre los estados parasitarios.
Because adults were found during the whole year, it is probable that the environmental conditions in the study area are suitable for a long survival of these stages. Thus, the period in that adults are found in the environment is probably related to the recruitment rates associated to host density. In the case of the immature, small mammals and birds are parasitized for immature (Bermúdez unpublished data). So far, in SMP it is no known as populations of mammals or birds vary throughout the seasons, knowing only the increase in the number of birds during the migration season (aprox. November-April), (12).

Two hypotheses can be sketched out to explain these results. One of this is related to host usage, because tick dispersion depends of host mobility. Haemaphysalis juxtakochi is a tick species with a wide range of hosts and there are records of adults parasitizing large and medium size mammal species belonging to different families such as Cervidae, Bovidae, Camelidae, Equidae, Tapiridae, Tayassuidae, Leporidae and Dasypodidae (13). The immature stages also appear to be catholic feeders, because they were found associated to different species of mammals (families Cervidae, Tayassuidae, Procyonidae, Sciuridae, besides Felidae, Canidae, Leporidae, Dasyproctidae, and Erethizontidae) and birds (families Turdidae, Emberizidae, Corvidae, Falconidae) (13). In Panama, the principal hosts of $H$. juxtakochi adults are Artiodactyla, especially white-tailed deer and peccaries (Bermúdez unpublished data), and of these, the white-tailed deer appear to be very common in west bank of the Panama Canal, wandering through forest and grass areas (14).

Thus, this capacity of $H$. juxtakochi to feed on hosts with different ecological preferences and, in several cases, a considerable vigility, allows rejecting the hypothesis that host usage determines a major number of ticks in WA. A second and more plausible hypothesis is based in the differences in microclimatic conditions between WA and GR (12). It is probable that microclimatic conditions in WA are better than those of GR to the development of the non-parasitic phase (moulting of engorged larvae and nymphs, oviposition of engorged females, incubation of eggs, host-seeking). This hypothesis agrees with the general idea of Ixodidae ticks are more habitat-specific than host-specific (12); however, further experimental studies on nonparasitic phase of $H$. juxtakochi should be designed to test this second hypothesis, besides complement with more data about parasitic phases. 


\section{Agradecimientos}

Este estudio fue patrocinado parcialmente por la Secretaría Nacional de Ciencia y Tecnología (COL07-045) y el ICGES. Agradecimientos especiales para el personal de la Autoridad Nacional del Ambiente, Parque Municipal Summit y Autoridad del Canal de Panamá por los respectivos permisos. A Red Iberoamericana de Investigación y Control de Enfermedades Rickettsiales (RIICER). Adicionalmente, agradecemos a INTA y CONICET por las asistencias financieras a SN.

\section{Acknowledgements}

This work was partially sponsored by Secretaria Nacional de Ciencia y Tecnología (grant COL-07045) and ICGES. Special thanks to personnel of the Autoridad Nacional del Ambiente, Parque Municipal Summit and Autoridad del Canal de Panama by the permission. To Red Iberoamericana de Investigación y Control de Enfermedades Rickettsiales (RIICER). Additionally, we acknowledge to INTA and CONICET for the financial assistances to SN.

\section{REFERENCES}

1. Bowman AS and Nuttall PA. Ticks biology, disease and control, New York: Cambridge University Press; 2008.

2. Dunn LH. The ticks of Panamá, their hosts, and the disease they transmit. Am J Trop Med 1923; 3:41-104.

3. Fairchild GB, Kohls GM, Tipton VJ. The ticks of Panama (Acarina: Ixodoidea). In: Wenzel WR and Tipton VJ editores. Ectoparasites of Panama. Chicago: Field Museum of Natural History; 1966; 167-219.

4. Bermudez SE, Miranda RJC, Smith DC. Ticks species (Ixodida) in the Summit Municipal Park and adjacent areas, Panama City, Panama. Exp Appl Acarol 2010; 52(4):439-48.

5. Bermudez SE, Miranda RJC. Distribution of ectoparasites of Canis lupus familiaris L. (Carnivora: Canidae) from Panama. Rev MVZ Córdoba 2011; 16(1):2274-2282.

6. Bermudez SE, Castro A, Esser $\mathrm{H}$, Liefting Y, García G, Miranda RJ. Ticks (Ixodida) on humans in Panama, Panama (2010-2011). Exp Appl Acarol 2012; 58(1):81-881.

7. Murgas IL, Castro AM, Bermúdez SE. Current status of Amblyomma ovale (Acari: Ixodidae) in Panama. Ticks and Tick-Borne Dis $2012 ; 4(1-2)$ : 164-166.

8. Cooley RA. The genera Boophilus, Rhipicephalus, and Haemaphysalis (Ixodoidea) of the New World. Bull Nat Inst Health 1946; (187):1-54.
9. Kohls GM. Records and new synonymy of new world Haemaphysalis ticks, with description of the nymph and larva of $H$. juxtakochi Cooley. J Parasitol 1960; 46:355-361.

10. Guglielmone AA, Estrada-Peña A, Keirans JE \& Robbins RG. Ticks (Acari: Ixodida) of the Neotropical Zoogeographic Region. Special Publication, International Consortium on Ticks Tick-borne Diseases Atalanta, Houten, The Netherlands 2003; 173:80-81.

11. Holdridge L. Life zone ecology. San Jose, Costa Rica: Trop. Sci. Center; 1967.

12. Saracco F, DeSante D, Alvarez C, Morales S, Milá B, Kaschube D, Michel N. Monitoreo de sobrevivencia invernal aparente de aves migratorias en el Neotrópico: Informe preliminar sobre los primeros dos años (2003-04) del programa Monitoreo de Sobrevivencia Invernal (MoSI). California: The Institute of Birds Populations; 2004.

13. Nava S, Guglielmone AA. A meta-analysis of host specificity in Neotropical hard ticks (Acari: Ixodidae). Bull Entomol Res 2013; DOI: $10.1017 /$ S0007485312000557.

14. Springer M, Carver A, Nielsen C, Correa N, Ashmore J, Ashmore J, Lee J. Relative abundance of mammalian species in a central Panamanian rainforest. Rev Lat Conserv 2013; 3(1):19-26. 